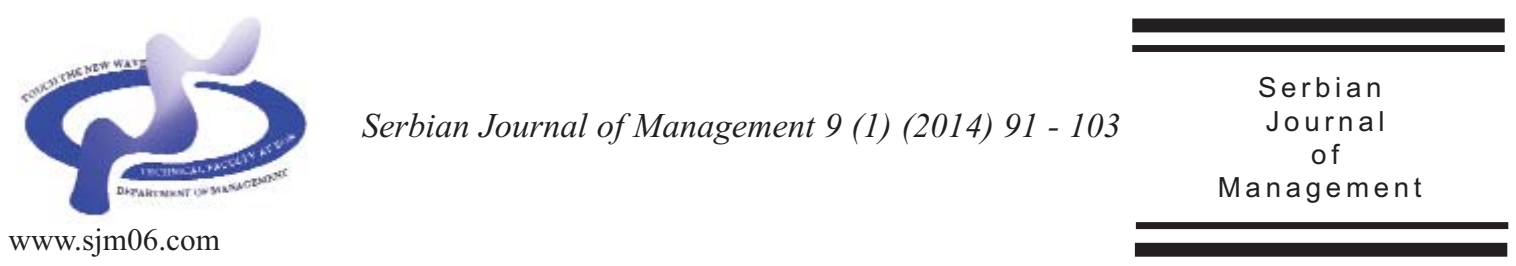

\title{
ASSESSING CUSTOMERS' PERCEIVED SERVICE QUALITY IN PRIVATE SECTOR BANKS IN INDIA
}

\author{
Rajeev Kumar Panda* and Rama Koteswara Rao Kondasani \\ School of Management, National Institute of Technology, Rourkela-769008, India
}

(Received 20 September 2013; accepted 14 April 2014)

\begin{abstract}
This paper aims at constructing a measure of service quality for Indian private sector banks. The SERVQUAL model was used. In total 28 variables were considered to find their relative importance from customers' point of view. Factor analysis was used to reduce redundant variables and finally four dimensions were identified that are the dependability with facility, guarantee, security with value added services and compassion with cordialness. Then RIDIT test was done to identify the prioritization pattern that customers assign to different variables. The result shows that customers believe that bank's effort in instill confidence in customers, the bank's concern for customers' best interest and safety standards in transactions are vital factors for improving customer satisfaction.
\end{abstract}

Keywords: Customer service, SERVQUAL, Private sector banks, RIDIT.

\section{INTRODUCTION}

Sound financial system is pivotal for the development and growth of a developing economy like India. Reviving and strengthening financial systems is a major challenge facing India because a sound financial system serve as an important channel for achieving economic growth through the mobilization of financial savings, putting them to productive use and transforming various risks (King \& Levin, 1993; Jayaratne \& Strahan, 1996; Rajan \& Zingales, 1998). India adopted a series of financial sector liberalization measures in the early 1990s that included interest rate liberalization, entry deregulations, reduction of reserve requirements and removal of credit allocation which have attracted increasing attention of investors across the globe. Of late Indian financial system and particularly banks are into a transition phase

\footnotetext{
* Corresponding author: panda.rajeevkumar@gmail.com

DOI:10.5937/sjm9-4511
} 
and adopting innovative marketing practices to attract and retain customers in order to grow their business. In India the banking system is characterized by a large number of banks with mixed ownership. As at end2012, the commercial banking segment comprised of 87 banks, including 26 stateowned banks (SOBs), 20 domestic private banks, including seven de novo private and 34 foreign banks. Total bank assets constituted over 90 per cent of GDP in 201112. In 1991, on the eve of financial reforms, SOBs share in total banking assets was a little over 90 per cent (Ghosh, 2013).

To survive in today's competitive business environment, banks need to focus on building and maintaining client relationships (Rootman et al., 2008; Abdullah \& Ramay, 2012). Within an intense competitive industry the bank that has the largest customer base and the highest customer retention rate will be a market leader in the industry (Khong \& Richardson, 2002). In this context the importance of implementing a sound customer service practices is becoming very vital. Today, many businesses such as banks, insurance companies, and other service providers realize the necessity to acquire new customers and retain existing ones. With appropriate customer service standards, banks could maximize the profits of each customer base (Best, 2005). This will require a strong understanding and coordination between different functionaries to provide a long-term retention of customers.

In order to be successful in the industry, banks must use their core competency to differentiate their services from the other competing players. Achieving that requires, inter alia, superior quality in customer services is the best option. Therefore, banks delivering quality of services better than their competitors would have greater possibilities of success (Tang \& Zairi, 1998). To understand service quality one must find out the factors those affect the level of the banks' service quality. However quantifying service quality is complicated and subjective too. This paper tries to explore the various factors that can improve the service delivery of private sector banks. The study was conducted in the city of Bhubaneswar and Rourkela city in the eastern part of India.

The next section assesses the current context of the Indian banking sector and the subsequent sections discuss the review of literature, methodology, data analysis \& interpretation and conclusion \& managerial implications respectively.

\section{INDIAN BANKING SECTOR}

Many developing economies including India are facing the central issues of strengthening the financial system. This is because sound financial systems serve as an important channel for achieving economic growth through the mobilization of financial savings, putting them to productive use and transforming various risks (King \& Levin, 1993; Jayaratne \& Strahan, 1996; DemirgüçKunt \& Maksimovic, 1998; Rajan \& Zingales, 1998; Beck et al., 1999). In last couple of decades Indian banking sector has seen significant changes and has witnessed a remarkable shift in its operating environment. Government has introduced different reform measures to revive the Indian banking sector and to meet the future challenges. The policy makers, which comprise the Reserve bank of India, Ministry of Finance and related government and financial sector regulatory entities have made several notable efforts to improve the 
overall health of the sector. More recently, liberalization, the opening up of the economy in the 90s and the government's decision to privatize banks by reduction of state ownership culminated in the banking reforms based on the recommendations of the Narasimham Committee, 1997. From the socialist thrust of the $70 \mathrm{~s}$ and $80 \mathrm{~s}$ when the nationalized banks operated with a view to giving access to organized banking to as many people as possible. The prime mover for banks today is profit, with clear indications from the government to "perform or perish". Banks have also started realizing that business depends on client service and the satisfaction of the customer and this is compelling them to improve customer service and build relationships with customers (Jha, 2000). Improved technologies in delivery systems, enhanced competition and processes have resulted in a paradigm shift in focus from price competition to service quality in the banking industry.

All aspects of the Indian banking sector are undergoing a sea change to offer better customer service, resource mobilization, credit management and forex management. Several innovative IT-based services such as Automated Teller Machines (ATMs), electronic fund transfer (EFT), anywhereanytime banking, smart cards, internet banking etc. are commonly implemented and offered to Indian banking customers (Rawani \& Gupta, 2000). The style of operation has completely changed and has become largely customer centric. Currently overall, banking in India is considered as fairly mature in terms of supply, product range and reacheven though reach in rural India still remains a challenge for both private sector and public sector banks.

The industry is currently in a transition phase. On the one hand, the public sector banks, which are the mainstay of the Indian banking system, are in the process of shedding their flab in terms of excessive manpower, excessive Non Performing Assets (NPAs) and excessive governmental equity, while on the other hand the private sector banks are consolidating themselves through mergers and acquisitions. Public sectors banks (PSBs) are currently accounting for more than 78 percent of total banking industry. The private players however cannot match the PSB's great reach, great size and access to low cost deposits and are somewhat lagging behind in the provision of innovative IT services.

In addition to the value added services customer service is the most important variable that can influence customer satisfaction and ultimately customer retention. This study focuses on prioritizing the service variables to increase customer loyalty particularly in private sector banks. In this competitive scenario, the key to success in the changing environment will be bank's ability to reach the client at his doorsteps, as well as the possibility for providing products and services in a customized manner (Bedi, 2010). Recently banks are using different marketing strategies to exceed customers' expectations and stay ahead in offering better service. Banks and particularly private sector banks have focused to develop service strategies to differentiate themselves from their competitors by providing high quality banking services.

\section{CUSTOMERS' PERCEIVED SERVICE QUALITY: REVIEW OF LITERATURE}

The following literature review section 
provides a discussion and argument for the selection of the variables for the empirical investigation. Many previous researchers (Lovelock, 1996; Haddad et al., 1998; Zeithaml, 2000; Andaleeb, 2001) have conducted research on customers' perception of the service quality attributes. Customers' perceived service quality (Zeithaml \& Bitner, 1996) and customer satisfaction (Oliver, 1997, Churchill \& Surprenant, 1982) are considered as the principal construct in the area of service marketing as eventually they lead to the effectiveness of consumer loyalty.

Reichheld and Sasser (1990) considered that raising customer satisfaction can increase their future loyalty. Lovelock (1996) indicated that customer satisfaction stems from a customer's comparison between his/her expectation about a particular product and his/her real experience of using this product. Also, customer satisfaction is the driving force of customer loyalty. Apparently, there is a positive relationship between customer satisfaction and customer loyalty. In other words, products or services with a higher customer satisfaction lead to better customer loyalty and customer maintenance. Anderson and Sullivan (1993) believed that customer satisfaction affects customers' repurchase behavior in a positive way, and a customers' repurchase behavior and his/her buying intention are one kind of customer loyalty. Furthermore, a satisfied customer is likely to be a loyal customer who will give repeating business to the bank (Heskett et al., 1997).

Banks have realized the fact that unless customer needs are taken into account in designing and delivering services, technical superiority will not bring success (Zeithaml \& Bitner, 1996). Many researchers (Brown \& Swartz, 1989; Lewis et al., 1994,
Gronroos, 1990) has argued that it is probably the effective measurement, management and improvement of service quality which will enable banking institutions to achieve a differential advantage over their competitors. Service quality, therefore, has become a critical prerequisite for satisfying and retaining valued customers in banks (Taylor \& Baker, 1994; Cronin \& Taylor, 1992). The interest is largely driven by the realization that high service quality results in customer satisfaction and loyalty with the product or service, greater willingness to recommend someone else, reduction in complaints and improved customer retention (Danaher, 1997; Levesque \& McDougall, 1996; Magi \& Julander, 1996).

While there is an established relationship between perceived service quality and customer' satisfaction and loyalty in the literature, the empirical investigation of this issue is rather complex. In particular, since the construct of customer satisfaction is latent in nature, the quantification of this construct is complex to understand. At the same time there are multiple dimensions that explain service quality. Parasuraman et al. (1988) have developed the most popular SERVQUAL models to use in service marketing. It is based on the perceived gap between the expectation from the service and performance of the service. Initially the model had 10 dimensions of service quality. Those are reliability, responsiveness, competence, access, courtesy, communication, credibility, security, understanding the consumer, and tangibles. Subsequently these were reduced to five dimensions which are reliability, responsiveness, empathy, assurances and tangibles by Parsuraman (1985). Another study by Zeithaml et al. (1993) illustrated the 
association between service quality and customer satisfaction. The model also assumed linearity between services attributes to performance with customer satisfaction (Tan \& Pawitra, 2001). In this paper, service attributes to performance in banks are defined within the service dimension of reliability, responsiveness, assurance, empathy and tangibles.

\section{RESEARCH METHODOLOGY}

Previous researchers (Carman, 1990; Babakus \& Boller, 1992) have found that service quality variables must be changed across service sectors. Haywood-Farmer and Stuart (1988) suggested that additional service dimensions in core service, service customization and knowledge and information be added to SERVQUAL. Brown and Swartz (1989) research of professional service quality perception found that "professionalism" and "professional competence" were significant factors for both providers and patients in the evaluation of service quality in healthcare sector. The present study proposes to investigate some additional SERVQUAL variables those may be of superior priority for customers in banking sector.

Data collection was done between July, 2012 and March, 2013 via a survey method using questionnaire as an instrument to record opinions of respondents. The questionnaire was then administered to respondents through face-to-face interviews. Face-to-face interviews were chosen because they have several advantages over the other methods. According to Bless and Smith (2000), a researcher-administered interview is an important tool of data collection because it reduces omission of difficult questions by respondents. In addition, it reduces the problem of word or question misinterpretation (misunderstandings). In addition, the presence of the interviewer increases the quality of the responses since the interviewer can probe for more specific answers (Leedy \& Ormrod, 2004).

The questionnaire measures the degree of agreeableness on various services quality attributes of banks. The respondents' opinions ranging from expected services and outcome of services within the five dimensions of service quality of Parsuraman SERVQUAL model (1985) were captured. The mode of contact with respondents was face-to-face in nine different private sector banks in the city of Rourkela and Bhubaneswar of eastern India. Bhubaneswar is the state capital where as Rourkela is a relatively small city with contrasting customers' lifestyle and exposure to innovative banking technology and practices.

Each bank was allotted 35 questionnaires. From the 315 questionnaires, 215 questionnaires were completed; a $68 \%$ response rate. 14 of them were discarded for further analyses due to too many missing values. Although the sample size was unlikely to generalise the population, it is sufficient to generate meaningful statistical results (Hair et al., 1998).

The questionnaire was designed to capture data that included demographic data on age, gender, educational qualification, income level (per month) and customer service parameters on service quality, convenience, service delivery, service promptness, relationship building measures etc. A series of statistical techniques were required before the quantification of service quality. These statistical analyses were conducted using AMOS SPSS-20; a widely 
used statistical software package. The statistical techniques conducted were reliability test, factor analysis and RIDIT test.

\section{DATA ANALYSIS INTERPRETATION}

AND

To measure and reassure the internal consistency, reliability test was conducted on the 28 variables bearing a Cronbach's alpha of 0.7 and above (Cronbach's alpha $=0.732$ ). This suggests that the questionnaire is measuring service quality in a meaningful way. Then factor analysis was used to remove the redundant (highly correlated) variables from the data and to reduce the number of variables into definite number of dimensions. The factor analysis is performed using the principal component extraction method with varimax rotation. The eigen values of selected factors were greater than 1. Table 1 shows the total variance explained by the factors extracted.

In the initial application, the number of variables was reduced from 28 to 20 . In the second application, these 20 variables were classified under four dimensions based on their factor-loading score. The sorted rotated values of factor loading with minimum value of 0.5 or more are considered. After dropping the redundant variables having all the four components loading less than 0.5 a matrix (in Table 2) was formed to understand the significant components that explain $84.14 \%$ of variance. Generally, factor loading represents how much a factor explains a variable. High factor loading i.e. more than 0.80 indicates that the factor strongly influences and has high impact on the variables. Here it may be said that some variables which has significantly less factor loading need attention for the service attributes quality improvement.

Based on the results of factor analysis, the variables were classified into four dimensions, which were suitably named. The dimensions and the corresponding variables are shown Table 3 . The analysis shows that the most vital factor stands for the common perception of the bank's customer about the dependability and facilities. This dimension includes promise, dependability, information, appearance and convenience. This reveals that the effectiveness of customer satisfaction is greatly influenced by the customers' opinion and perception about the reliability and facilities aspect. They feel more attached to the bank if and only if the above mentioned criteria are fulfilled. The other factor is related to the variables like how employees of the bank take care of the customers' best interest and instill confidence in customers. These two factors reflect assurance. Now-a-days it is very important for banks to first assure the customers that their interest will be given utmost priority. The bank also should keep the confidence of the customers high by always solving their queries from time to time. Variables like the willingness of the bank's staff and their quick response to customers, safety in transaction, different facilities like ATM and Internet service are also important for enhancing customer satisfaction. One aspect which customers dislike is the complicated paper. Again empathy and cordial nature of the bank's employee towards customers is very vital according to the customers. The customers value the bank's ability to understand the needs and the behaviour of banks staff towards customers. The bank should communicate these common etiquettes to the employees that will raise their morale. 
Table 1. Total Variance Explained

\begin{tabular}{|c|c|c|c|c|c|c|c|c|c|}
\hline \multirow[t]{2}{*}{ Cmpnt } & \multicolumn{3}{|c|}{ Initial Eigen values } & \multicolumn{3}{|c|}{$\begin{array}{c}\text { Extraction Sum Squared } \\
\text { Loadings }\end{array}$} & \multicolumn{3}{|c|}{$\begin{array}{c}\text { Rotation Sum Squared } \\
\text { Load }\end{array}$} \\
\hline & Total & $\begin{array}{l}\% \text { of } \\
\text { Varian }\end{array}$ & Cumul \% & Total & $\begin{array}{l}\% \text { of } \\
\text { Var }\end{array}$ & Cumul \% & Total & V & $\begin{array}{c}\text { Cumul } \\
\%\end{array}$ \\
\hline 1 & 18.865 & 67.375 & 67.375 & 18.865 & 67.375 & 67.375 & 17.949 & 64.10 & 64.105 \\
\hline 2 & 2.063 & 7.368 & 74.743 & 2.063 & 7.368 & 74.743 & 2.361 & 8.43 & 72.535 \\
\hline 3 & 1.503 & 5.369 & 80.112 & 1.503 & 5.369 & 80.112 & 1.940 & 6.92 & 79.462 \\
\hline 4 & 1.128 & 4.029 & 84.141 & 1.128 & 4.029 & 84.141 & 1.310 & 4.67 & 84.141 \\
\hline 5 & .982 & 3.505 & 87.646 & & & & & & \\
\hline 6 & .849 & 3.033 & 90.679 & & & & & & \\
\hline 7 & .714 & 2.548 & 93.228 & & & & & & \\
\hline 8 & .502 & 1.791 & 95.019 & & & & & & \\
\hline 9 & .313 & 1.118 & 96.137 & & & & & & \\
\hline 10 & 280 & 1.000 & 97.137 & & & & & & \\
\hline 11 & 215 & .769 & 97.906 & & & & & & \\
\hline 12 & 191 & .680 & 98.586 & & & & & & \\
\hline 13 & 149 & .531 & 99.117 & & & & & & \\
\hline 14 & .081 & 288 & 99.406 & & & & & & \\
\hline 15 & .060 & .215 & 99.621 & & & & & & \\
\hline 16 & .049 & .175 & 99.795 & & & & & & \\
\hline 17 & .029 & .102 & 99.897 & & & & & & \\
\hline 18 & .013 & .045 & 99.942 & & & & & & \\
\hline 19 & .009 & .031 & 99.973 & & & & & & \\
\hline 20 & .007 & .026 & 99.999 & & & & & & \\
\hline 21 & .000 & .001 & 100.000 & & & & & & \\
\hline 22 & $2.241 \mathrm{E}-15$ & $8.004 \mathrm{E}-15$ & 100.000 & & & & & & \\
\hline 23 & $6.102 \mathrm{E}-16$ & $2.179 \mathrm{E}-15$ & 100.000 & & & & & & \\
\hline 24 & $4.368 \mathrm{E}-16$ & $1.560 \mathrm{E}-15$ & 100.000 & & & & & & \\
\hline 25 & $-2.548 \mathrm{E}-17$ & $-9.100 \mathrm{E}-17$ & 100.000 & & & & & & \\
\hline 26 & $-3.526 \mathrm{E}-17$ & $-1.259 \mathrm{E}-16$ & 100.000 & & & & & & \\
\hline 27 & $-3.381 \mathrm{E}-16$ & $-1.208 \mathrm{E}-15$ & 100.000 & & & & & & \\
\hline 28 & $-6.182 \mathrm{E}-16$ & $-2.208 \mathrm{E}-15$ & 100.000 & & & & & & \\
\hline
\end{tabular}

Extraction Method: Principal Component Analysis.

Table 2. Rotated Component Matrix

\begin{tabular}{|c|c|c|c|c|}
\hline & \multicolumn{4}{|c|}{ Component } \\
\hline & 1 & 2 & 3 & 4 \\
\hline Promise & .846 & & & \\
\hline Dependability in problem solving & .516 & & & \\
\hline Error free records & .940 & & & \\
\hline Service Information & .773 & & & \\
\hline Appealing facilities & .963 & & & \\
\hline Professional appearance & .940 & & & \\
\hline Appealing material & .972 & & & \\
\hline Places to relax & .935 & & & \\
\hline Neat and clean & .869 & & & \\
\hline Convenience business hour & .947 & & & \\
\hline Convenient branch location & .933 & & & \\
\hline Never too busy to respond & & & .947 & \\
\hline Safety & & & .663 & \\
\hline ATM facilities & & & 609 & \\
\hline Internet service & & & .964 & \\
\hline Complicated Paper work & & & .745 & \\
\hline Understanding need & & & & .957 \\
\hline Cordial front office staff & & & & .666 \\
\hline Customers' best interest & & .965 & & \\
\hline Instill confidence in customers & & 964 & & \\
\hline
\end{tabular}

Extraction Method: Principal Component Analysis.Rotation Method: Varimax- Kaiser Normalization. 
Table 3. Factors influencing Customer service quality

\begin{tabular}{ccl}
\hline S.N. & \multicolumn{1}{c}{ Dimensions } & \multicolumn{1}{c}{ Variables/Dimensions } \\
\hline 1 & Dependability and Facility & a. Promise \\
& & b. Dependability in problem solving \\
& c. Error free records \\
& d. Service Information \\
& e. Appealing facilities \\
& f. Professional appearance \\
& g. Appealing material \\
& h. Places to relax \\
& i. Neat and clean \\
& & j. Convenience business hour \\
& & k. Convenient branch location \\
& & a. Customers' best interest \\
& & b. Instill confidence in custom \\
& & a. Never too busy to respond \\
& & b. Safety \\
& & c. ATM facilities \\
& security and value added & d. Internet service \\
& & e. Complicated Paper workers \\
& & a. Understanding need \\
& & b. Cordial front office staff \\
& &
\end{tabular}

After finding out the different constructs for service variables, RIDIT analysis (See Appendix for calculation) was done to find out the relative importance of different variables from customers' point of view. RIDIT analysis is "distribution free" in the sense that it makes no assumption about the distribution of the population under study
(Bross, 1958). All the 20 variables were ranked using this test and the following results were found. Since the Kruskal-Wallis $W$ (441.6) is significantly greater than $\chi^{2}$ $(20-1)=30.1$, it can be inferred that the opinions about the scale items among the respondents are statistically different (Table 4). Now it is evident from the RIDIT test that

Table 4. RIDIT ranking of service variables

\begin{tabular}{lcc}
\hline Variables & $\begin{array}{c}\text { RIDIT Values }\left(\rho_{i}\right) \\
\text { for comparison data set }\end{array}$ & RIDIT Ranking \\
\hline Promise & 0.5206 & 8 \\
Dependability in problem solving & 0.4509 & 4 \\
Error free records & 0.5688 & 10 \\
Service Information & 0.6379 & 17 \\
Appealing facilities & 0.5927 & 12 \\
Professional appearance & 0.6501 & 19 \\
Appealing material & 0.6534 & 20 \\
Places to relax & 0.6091 & 13 \\
Neat and clean & 0.6189 & 15 \\
Convenience business hour & 0.6123 & 14 \\
Convenient branch location & 0.5454 & 9 \\
Never too busy to respond & 0.5844 & 11 \\
Safety & 0.4390 & 3 \\
ATM facilities & 0.5109 & 6 \\
Internet service & 0.6201 & 16 \\
Complicated Paper work & 0.5149 & 7 \\
Understanding need & 0.5002 & 5 \\
Cordial front office staff & 0.6461 & 18 \\
Customers' best interest & 0.4323 & 2 \\
Instill confidence in customers & 0.3625 & 1 \\
\hline
\end{tabular}

Kruskal-Wallis $\mathrm{W}=441.6 ; \chi^{2}(20-1)=30.1$ 
when it comes to service quality customer gives priority to factors like the way bank employees instill confidence in customers and how do they understand the best interest of the customers. In contrast to these, safety is an additional important factor in banking transaction which is ranked as the third most important variable. Good ATM facility and uncomplicated paperwork are also two major criteria of better service quality for customers.

\section{CONCLUSION \& MANAGERIAL IMPLICATION}

From the findings of the study it is evident that in order to benefit from the service quality, banks must constantly benchmark their service levels based on their service attributes. The study has identified some prime factor of concern for banking customers and identified the area of inadequacies in their service quality that could possibly be the biggest threat for superior customer satisfaction. Several managerial implications emerge from this study. While the findings and guidelines offered in this study hold promise, they should not be viewed as panacea. The ultimate success of any quality program implemented by bank can duly be ganged by creation and retention of satisfied customers. At the same time, to deliver high quality services to their customers, banks should not ignore the specific needs of their employees such as motivation factors, factors leading to satisfaction (or dissatisfaction) among them, ways and means to enhance employees' commitment to their jobs, customers and the institutions they work for must be addressed properly. Although the study expands the knowledge of service quality, viable prospects for future research remains. The scope of this present research may be extended as a comparative study of service quality between public and private sector banks. It can be extended to other service industries like healthcare, hospitality etc. Future research efforts could also concentrate in building a broader conceptual model of factors that influence perceived service quality.

In the present study the researcher attempted to be as scientific as possible, nevertheless there are some limitations. The measures included in this research were all based upon the perceptions of the banks' customers. So data inaccuracies due to misinterpretation or predisposition can not be ruled out. Secondly, the present research is carried out in two small cities of India viz. Rourkela and Bhubaneswar. The perception of people may vary from those of the rest of India. A careful selection of a better representative sample from all across India would bring comprehensiveness in the results.

\section{References}

Abdullah, Ramay, M.I. (2012). Antecedents of organizational commitment of banking sector in Pakistan. Serbian Journal of Management, 7(1), 89-102.

Andaleeb, S.S. (2001). Service quality perceptions and patient satisfaction: a study of hospitals in a developing country. Social Science \& Medicine, 52, 1359-1370.

Anderson, E.W., \& Sullivan, M.W. (1993). The antecedents and consequences of customer satisfaction. Marketing Science, 12, 125-143.

Babakus, E., \& Boller, G.W. (1992). An Empirical Assessment of the SERVQUAL 


\title{
ПРОЦЕНА КВАЛИТЕТА УСЛУГА ОД СТРАНЕ КЛИЈЕНАТА ПРИВАТНИХ БАНАКА У ИНДИЈИ
}

\author{
Rajeev Kumar Panda, Rama Koteswara Rao Kondasani
}

\section{Извод}

Овај рад има за циљ доприносу мерењу квалитета услуга у индијским проватним банкама. Коришћена је методологија "SERVQUAL" модела. Посматрано је укупно 28 промењивих како би се нашао њихов релативни значај, из угла посматрања клијената. Потом је примењена факторска анализа која је смањила редунданцу промењивих. На тај начин идентификовано је четири димензија. Потом је урађен "RIDIT" тест да би се идентификовала приоретизација купаца разматраних услуга. Резултати су показали да су то труд банака на развоју поверења купаца, брига банака о најбољем интересу клијената као и стандарди безбедности у трансакцијама клијената, као најзначајнији фактори задовољства корисника.

Кључне речи: Услуга клијената, "SERVQUAL”, Банке приватног сектора, "RIDIT”

Scale. Journal of Business Research, 24 (3), 253-268.

Beck, T., Levin, R., \& Loayza, N. (1999). Finance and the sources of growth, The World Bank, Policy Research Working Paper Series 2057.

Bedi, M. (2010). An integrated framework for service quality, customer satisfaction and behavioral responses in Indian banking industry - a comparison of public and private sector banks. Journal of Services Research, 10 (1), 157-172.

Best, R. (2005). Market based management, 4th International 3 ed., Maidenhead, UK: McGraw Hill.

Bless, C., \& Smith, H.C. (2000). Fundamentals of social research methods: An African perspective (3rd edition). Lansdowne, South Africa: Juta.

Bross, I. (1958). How to Use RIDIT Analysis. Biometrics, 14 (1), 18-38.

Brown, S., \& Swartz, T.A. (1989). A Gap Analysis of Professional Service Quality. Journal of Marketing, 53 (4), 92-98.

Carman, J.M. (1990). Consumer
Perceptions of Service Quality: An Assessment of the SERVQUAL Dimensions. Journal of Retailing, 66 (1), 33-55.

Churchill, G.A.Jr., \& Carol, S. (1982). An investigation into the determinants of customer satisfaction. Journal of Marketing Research, 19, 491 -504.

Cronin, J.J., \& Taylor, S.A. (1992) Measuring Service Quality: A ReExamination and Extension. Journal of Marketing, 56 (7), 55-68.

Danaher, P.J. (1997) Using Conjoint Analysis To Determine The Relative Importance Of Service Attributes Measured In Customer Satisfaction Surveys. Journal of Retailing, 17 (2), 235-260.

Demirgüç-Kunt, A., \& Maksimovic, V. (1998). Law, finance, and firm growth. Journal of Finance, 53 (6), 2107-2137.

Ghosh, S. (2013). Macroprudential regulation and bank performance: Evidence from India, Reserve Bank of India Working Paper Series (DEPR): 08/2013, Department of Economic and Policy Research.

Gronroos, C. (1990). Service 
management and marketing. Lexington, USA: Lexington Books, M.A.

Haddad, S., Fournier, P., Machouf, N., \& Yatara, F. (1998). What does quality mean to lay people? Community perceptions of primary care services in Guinea. Social Science \& Medicine, 47, 381-394.

Hair, J.F., Anderson, R.E., Tatham, R.L., \& Black, W.C. (1998). Multivariate Analysis (5th ed.). New Jersey: Prentice Hall International.

Haywood-Farmer, J., \& Stuart, F.I. (1988). Measuring the Quality of Professional Services. The Management of Service Operation proceedings of the 3rd Annual International Conference of the UK Operations Management Association.

Heskett, J.L., Sasser, W.E., \& Schlesinger, L.A. (1997). The service profit chain. New York, USA: The Free Press.

Jayaratne, J., \&. Strahan, P.E. (1996). The finance-growth nexus: evidence from bank branch deregulation. Quarterly Journal of Economics, 111, 639-670.

Jha, S.M. (2000). Bank marketing. Millennium Edition, Mumbai, India: Himalaya publication.

King, R.G., \& Levine, R. (1993). Finance and growth: Schumpeter might be right. Quarterly Journal of Economics, 108 (3), 713-737.

Khong, K.W., \& Richardson, S. (2002). Business Process Re-engineering: a comparison with other management techniques. The Journal of the Institute of Bankers Malaysia, 4 (119), 32-44.

Leedy, P., \& Ormrod, J. (2004). Practical research: Planning and design. 8th Edition, New York, USA: Prentice hall.

Levesque, T., \& McDougall, G.H.G. (1996). Determinants of Customer Satisfaction in Retail Banking. International Journal of Bank Marketing, 14, 12-20.
Lovelock, C.H. (1996). Service marketing, Englewood Cliffs. NJ, USA: Prentice Hall.

Magi, A., \& Julander, C.R. (1996). Perceived Service Quality and Customs Satisfaction in a Store Performance Framework. Journal of Retailing and Consumer Services, 11 (1), 33-41.

Narasimham Committee Report (1997). http://www.indianembassy.org/enews/ apr98.pdf, assessed on 21.04.2013.

Oliver, R.L. (1997). Satisfaction: A behavioral perspective on the consumer. New York, USA: McGraw-Hill.

Parasuraman, A., Zeithaml. V.A., \& Berry, L.L. (1985). A conceptual model of service quality and its implications for future research. Journal of Marketing, 49, 41-50.

Parasuraman, A., Zeithaml, V.A., \& Berry, L.L. (1988). SERVQUAL: A Multiple-Item Scale for Measuring Consumer Perceptions of Service Quality. Journal of Retailing, 64 (1), 12-40.

Rajan, R.G., \& Zingales, L. (1998). Financial systems, industrial structure, and growth, Unpublished manuscript, Chicago University.

Rawani, A \& Gupta, M. (2000). TVs service quality in banks, in Raghavachari, M. and Ramani, K. (Eds), A few learning issues in delivering service quality: Managerial challenges in 21st century, Macmillan, New Delhi.

Reichheld, F.F., \& Sasser, W.E. (1990). Zero defections: Quality comes to services. Harvard Business Review, 68, 105-111.

Rootman, C., Tait, M., \& Bosch, J. (2008). Variables influencing the customer relationship management of banks. Journal of Financial Services Marketing, 13 (1), 52-62.

Tan, K.C., \& Pawitra, T.A. (2001). Integrating SERVQUAL and Kano's model 
into QFD for service excellence development. Managing Service Quality, 11 (6), 418-430.

Tang, K.H., \& Zairi, M. (1998). Benchmarking quality implementation in a service context: A comparative analysis of financial services and institutions of higher education, Part I: Financial services sector. Total Quality Management, 9(6), 407-420.

Taylor, S., \& Baker, T. (1994). An Assessment of the Relationship between Service Quality and Customer Satisfaction in the Formation of Consumer's Purchase Intentions. Journal of Retailing, 70 (2), 163178.

Zeithaml, V.A., Berry, L.L., \& Parasuraman, A. (1993). The nature and determinants of customer satisfaction of services. Journal of the Academy of Marketing Science, 21 (1), 1-12.

Zeithaml, V.A., \& Bitner, J.M. (1996). Services marketing. New York, USA: Mc Graw-Hill.

Zeithaml, V.A. (2000). Service quality, profitability and economic worth of customers: what we know and we need to learn. Academy of Marketing Science Journal, 28(1), 67-85. 


\section{APPENDIX}

\section{RIDIT Analysis:}

The term stands for "Relative to an Identified Distributions" and is a probability transformations based on some empirical distributions that is taken as a reference class. Ridit is a weight assigned to a response category that reflects the probability of that category appearing in the reference distributions. A ridit has a range that approaches the limits of 0.000 at one end and 1.000 at the other. For example, there are $m$ items and $n$ ordered categories listed from the most favoured to the least favoured in the scale. The computation of ridits for the reference data set would be as follows:

1. (a) Then the frequency $f_{j}$ for each category of responses, where $j=1 \ldots n$ are computed.

(b) Mid-point accumulated frequency $F j$ for each category of responses. $\mathrm{F}_{1}=1 / 2 \mathrm{f}_{1}$

$$
\mathrm{F}_{\mathrm{j}}=1 / 2 \mathrm{f}_{\mathrm{j}}+\sum_{k=1}^{j-1} f k \text { where } \mathrm{j}=2, \ldots \ldots, \mathrm{n}
$$

(c) Ridit value $R j$ for each category of responses in the reference data set.

$$
R_{j}=F_{j} / N \text {, where } j=1 \ldots n
$$

( $N$ is the total number of responses Expected value of $R$ for the reference data set is 0.5.)

2. Then a comparison data set is comprised of the frequencies of responses for each category of a Likert scale item.

(a) Ridit value $r_{i j}$ for each category of scale items. $\mathrm{r}_{\mathrm{ij}}=\left(\mathrm{R}_{\mathrm{j}} \times \pi_{\mathrm{ij}}\right) / \pi_{\mathrm{i}}$, where $\mathrm{i}=1, \ldots, \mathrm{m}$

$\pi_{i j}$ is the frequency of category $j$ for the ith scale item, and $\pi_{i}$ is a short form for the summation of frequencies for scale item $i$ across all categories, i.e. $\pi_{i}=\sum_{1}^{n} \pi_{k}$

(b) Mean ridit $\boldsymbol{\rho}_{i}$ for each Likert scale item. $\boldsymbol{p}_{i}=\sum_{k=1}^{n} r i k$

(c) Confidence interval for $\rho_{i}$. When the size of the reference data set is very large to that of any comparison data set, the $95 \%$ confidence interval of any $\rho_{i}$ is: $\mathrm{p} \pm 1 / \sqrt{3 \Pi i}$

3. Testing the following hypothesis using Kruskal-Wallis statistics $W$.

$$
\begin{aligned}
& \text { Ho: } \forall i, p i=0.5 \quad \text { Ha: } \exists i, p i \neq 0.5 \\
& \mathrm{~W}=12 \sum_{i=1}^{m} \Pi i(p i-0.5)^{2}
\end{aligned}
$$

W follows a $\chi 2$ distribution with (m-1) degree of freedom. If $\mathrm{H}_{0}$ cannot be accepted, examine the relationships among confidence intervals of $\rho$. 